\title{
NUMERICAL MODELLING OF BIRD STRIKE ON A ROTATING ENGINE BLADES BASED ON VARIATIONS OF POROSITY DENSITY
}

\author{
Sharis-Shazzali SHAHIMI ${ }^{1}$, NUR AZAM AbdUllah ${ }^{1}$, \\ MEFTAH HRAIRI ${ }^{1}$, AMEEN TOPA ${ }^{2,3}$ AND AHMAD FARIS ISMAIL ${ }^{1}$

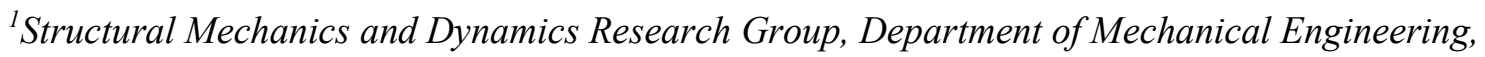 \\ International Islamic University Malaysia, \\ Jalan Gombak, 53100 Kuala Lumpur, Malaysia \\ ${ }^{2}$ Insitute of Transportation Infrastructure, Universiti Teknologi PETRONAS, \\ Seri Iskandar, 32610, Malaysia \\ ${ }^{3}$ Faculty of Ocean Engineering Technology and Informatics, Universiti Malaysia Terengganu, \\ Kuala Terengganu, 21300, Malaysia \\ *Corresponding author: azam@iium.edu.my
}

(Received: $14^{\text {th }}$ July 2021; Accepted: $21^{\text {st }}$ September 2021; Published on-line: $4^{\text {th }}$ January 2022)

\begin{abstract}
A numerical investigation is conducted on a rotating engine blade subjected to a bird strike impact. The bird strike is numerically modelled as a cylindrical gelatine with hemispherical ends to simulate impact on a rotating engine blade. Numerical modelling of a rotating engine blade has shown that bird strikes can severely damage an engine blade, especially as the engine blade rotates, as the rotation causes initial stresses on the root of the engine blade. This paper presents a numerical modelling of the engine blades subjected to bird strike with porosity implemented on the engine blades to investigate further damage assessment due to this porosity effect. As porosity influences the decibel levels on a propeller blade or engine blade, the damage due to bird strikes can investigate the compromise this effect has on the structural integrity of the engine blades. This paper utilizes a bird strike simulation through an LS-Dyna Pre-post software. The numerical constitutive relations are keyed into the keyword manager where the bird's SPH density, a $10 \mathrm{~ms}$ simulation time, and bird velocity of $100 \mathrm{~m} / \mathrm{s}$ are all set. The blade rotates counter-clockwise at $200 \mathrm{rad} / \mathrm{s}$ with a tetrahedron mesh. The porous regions or voids along the blade are featured as $5 \mathrm{~mm}$ diameter voids, each spaced $5 \mathrm{~mm}$ apart. The bird is modelled as an Elastic-Plastic-Hydrodynamic material model to analyze the bird's fluid behavior through a polynomial equation of state. To simulate the fluid structure interaction, the blade is modelled with Johnson-Cook Material model parameters of aluminium where the damage of the impact can be observed. The observations presented are compared to previous study of a bird strike impact on non-porous engine blades.
\end{abstract}

ABSTRAK: Penyelidikan berangka telah dijalankan ke atas bilah enjin berputar tertakluk kepada impak pelanggaran burung. Pelanggaran burung tersebut telah dimodelkan secara berangka sebagai silinder gelatin dengan hujungnya berbentuk hemisfera demi mensimulasikan impaknya ke atas bilah enjin yang berputar. Pemodelan berangka bilahbilah enjin yang berputar tersebut menunjukkan bahawa pelanggaran burung mampu menyebabkan kerosakan teruk terhadap bilah enjin terutamanya apabila bilah enjin sedang berputar oleh sebab putaran menghasilkan tekanan asal di pangkal bilah enjin. Kajian ini mengetengahkan pemodelan berangka ke atas bilah-bilah enjin tertakluk kepada pelanggaran burung terhadap bilah-bilah enjin yg mempunyai keliangan demi menyelidik dan menilai kerosakan kesan daripada keliangan tersebut. Keliangan juga mempengaruhi tahap-tahap desibel ke atas bilah kipas ataupun bilah enjin, kerosakan hasil serangan 
burung boleh menterjemah tahap ketahanan struktur integriti bagi bilah-bilah enjin tersebut. Penyelidikan ini mengguna pakai perisian "LS-Dyna Pre-post" untuk simulasi pelanggaran burung. Hubungan konstitutif berangka telah dimasukkan sebagai kata kunci di mana ketumpatan SPH burung, masa simulasi $10 \mathrm{~ms}$, dan halaju burung ditetapkan kepada $100 \mathrm{~m} / \mathrm{s}$. Bilah tersebut berputar pada $200 \mathrm{rad} / \mathrm{s}$ arah lawan jam dengan jejaring tetrahedron. Kawasan berliang atau kosong di sepanjang bilah ditetapkan diameternya kepada $5 \mathrm{~mm}$, dan dijarakkan $5 \mathrm{~mm}$ di antara satu sama lain. Burung pula dimodelkan sebagai material "Elastic-Plastic-Hydrodynamic" untuk mengkaji sifat bendalir burung melalui persamaan polinomial. Demi mensimulasi interaksi struktur bendalir, bilah tersebut dimodelkan sebagai parameter aluminium material "Johnson Cook" di mana kerosakan daripada impak tersebut dapat diteliti. Penelitian-penelitian tersebut dibandingkan dengan kajian terdahulu ke atas serangan burung terhadap bilah-bilah enjin tidak berliang.

\section{KEYWORDS: bird strike; rotating engine blades; porosity; SPH; structural damage}

\section{INTRODUCTION}

Bird strikes are one of the most dangerous phenomena threatening aircraft in aviation today. As bird strikes can cause severe damage to an aircraft, especially during take-off and landing, numerous attempts must be made to ensure aircraft are structurally robust, strong, and able to withstand high speed impacts. These birds can strike at any part of the aircraft such as the wings, parts of the fuselage, the windscreen, and the engine. Research and experimentations are important to predict and analyze these bird strike impacts as bird strikes have become more frequent in recent times [1]. Many aircraft, civilian and military, have been destroyed or damaged by bird strikes; increasing aircraft expenses and lives lost due to these dangerous strikes, calling for a need to make aircraft parts more robust.

Although birds can strike at any part of the aircraft, the engine is the most dangerous part the bird can impact. If the engines are damaged, this can cause the pilot to lose control of the aircraft, prompting the pilot to attempt an emergency landing. As such, the aircraft must have sufficient power to land safely in the event of bird impact. In the specific event of bird impact to the engine, bird strikes will most probably damage the engine, causing the aircraft to crash land and destroy the aircraft, losing many lives. It is essential to predict and assess these bird strikes on the engine turbine blades during flight.

Bird strikes were already tested through experimentation during the early $80 \mathrm{~s}$. The earliest experimental tests were conducted by Wilbeck [2]. The basis of the experimental procedures was conducted through Liu et al. [3] on flat plates and Guan et al. [4] with fan rotor blades. In these experiments, the bird was modelled as a fluid structure and the design of the bird changed over the years from a spherical model, to cylindrical model, and into the hemispherical-ended cylinder that is the most frequent model in use today. The bird's mass density is modelled as a gelatin structured bird that can be fired onto the aircraft part, thus analyzing the damage of the aircraft part.

Numerical simulations have since been more in favor as compared to experimentation. Throughout the years, experimentation has become expensive by damaging aircraft parts during testing, and repeated use of gelatin synthetic birds is unsanitary. However, Wilbeck's experiment basis has since been discussed, referred, and verified by other researchers today. The discussions of these impacts to engine blades state that the bird transfers its momentum to the engine blades due to the oscillations of the blade's rotation [2]. Wilbeck analyzed these oscillations and blade response to accurately predict the impact loads of the synthetic 
birds. With these impact loads, comparisons can be made with several different types of aircraft parts impacted by bird strikes.

\section{BIRD STRIKE ENGINE BLADE STRUCTURAL INTEGRITY}

Many numerical simulations have been conducted and expanded pertaining to the structural integrity and materials of aircraft structures [5]. These works discuss the damage and cracking of several aircraft wing boxes. Bird strikes must be considered in these research analyses as part of the impact loads that can cause these damage threats to the aircraft structural integrity, especially to the aircraft engine's blades, as mentioned. There is a gap in the research pertaining to the structural damage on engine blades where the engine blade's rotational oscillations are involved. Most of the research on bird strikes have shown the blade as static where there is in fact blade rotation. There is currently a gap in analysis and numerical modelling in which bird strike impacts the blades as dynamic rotations. A numerical analysis conducted by Shahimi et al. [8] and Vignjevic et al. [9] has shown that centrifugal forces due to rotation contribute to the loads and stresses experienced by the engine blades as they rotate. Both these analyses assess the damage of a numerically modelled engine blade subjected to bird strike impact. Even after impact, the stresses persist and affect the structural integrity of the blade.

Research on aviation has also expanded to include porosity in the wings and blade structure [10], pertaining the need to further expand the scope of bird strike impact on these types of configurations. Porosity on aircraft wings and blades have an adverse effect on these aircraft parts in that it can weaken the structural integrity of those mentioned parts due to the holes punctured on the surface of the wing or blade. The trade-off here would be to analyze the damage if such a configuration were to be established on the aircraft parts versus the advantages that porosity offers. The aerodynamics of a porous wing were presented as variations in lift coefficient, drag coefficient, and lift versus drag as a function of porosity. These aerodynamic factors had the adverse effect that porosity on the wing structure shows close agreement with the behavior of the lift coefficient slope and a similar trend in the performance of the lift slope [10]. However, these aerodynamic changes due to porosity, while good, must be analyzed with the structural compromise that might happen in a bird strike event.

Similarly, methods of reducing noise on aircraft propeller blades were presented where an experimental investigation on the effect of a 'butterfly acoustical skin' on the acoustic performance of two-bladed propellers with a rotational speed [11]. The paper discusses different micro and nanostructures of porous scales, applying it fully to the skin surface of a two-bladed propeller. The experiment's measurements of noise frequency on the porous surface skin are significant, where even a small diameter hole of around $0.5 \mathrm{~mm}$ to $1.25 \mathrm{~mm}$ can reduce the wave drag and large side forces and redistribute the pressure on the outer surface by establishing communication between high- and low-pressure regions in the holes on the surface of the blade. The studies show that noise reduction of as much as $4 \mathrm{~dB}$ for a rotating propeller with a 'butterfly acoustical skin' with a porous region compared to a hollow region with $2 \mathrm{~dB}$ [11]. This is a good step into more silent propellers in aviation but as with the mentioned aerodynamics of a wing, this has an adverse effect on the structural integrity of the blade structure in the event of a bird strike.

Based on all these analyses and observations, this paper assesses the damage of a porous engine blade subjected to a bird strike impact. The numerical simulation was conducted with an LS-Dyna prepost software to visualize a rotational porous engine blade impacted by an SPH bird model with mass and density parameters [12]. This numerical analysis method 
was validated through a study of parametric engine blades by Vignjevic et al. [9]. The engine blade structure was modelled with $5 \mathrm{~mm}$ diameter holes punctured on the leading edge of the blades and a Johnson-Cook failure model constant was implemented through the LSDyna keyword manager.

\section{BIRD MODEL}

\subsection{Bird Geometry and SPH}

In bird strike analysis, establishing the method, geometry and bird model is an essential part of the numerical analysis. The Smoothed Particle Hydrodynamics (SPH) method is the most common and widely used in numerical simulations for any bird strike cases. Various approaches and other methods were presented and compared to be referred in a single study to differentiate the approaches to bird strike modelling [13].

The Lagrangian Method and the Rigid Bird Model are presented. The method presents the bird model as a geometry mesh with distinctive shapes, whether spherical, cylindrical, or cylindrical with hemispherical ends. However, a cylinder with hemispherical ends does more closely resemble an artificial bird. This model can establish a better bird pressure history in real time with more accuracy during testing. The Lagrangian and Bird Rigid Body method, however, shows that during the impact of the bird, the meshes move together and are not treated as individual particles. As the bird impacts the aircraft, large indentations on the aircraft part would show damage at the point of splatter impact with the bird, concentrating the splatter to a single point, rather than to a more diverse splatter that a real bird would produce.

This is the advantage that the SPH method can present, where each individual particle of the mesh distortions carries the mass, velocity and material law assigned to each particle. As the splatter occurs, a more diverse spread is shown beyond the point of impact, where each particle would then impact other parts of the aircraft, damaging the parts and accurately predicting the analysis. Figure 1 presents the SPH model of the bird used in this numerical analysis.

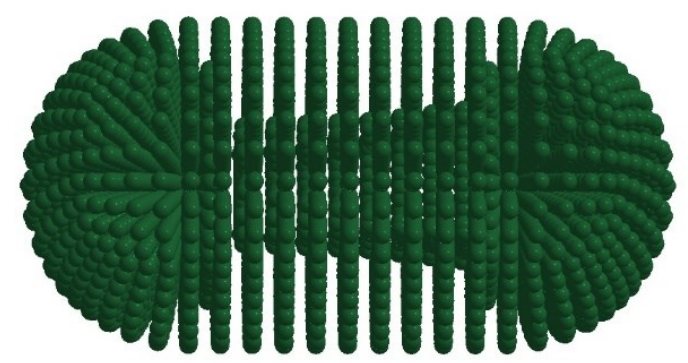

Fig. 1: Bird model SPH. Length to radius ratio equal to two.

\subsection{Bird Parameters and Material Model}

The bird parameters are first established as density and diameter of the hemisphere as a function of the bird's mass. The equations are revised by Banerjee et al. [14] as the Johnson Cook failure constants are also established together further in the paper. The equations of density and diameter of the bird model are presented below:

$$
\rho=-0.063\left(\log _{10} m\right)+1.148
$$

Based on these two relationships, with a density $\rho=950 \mathrm{~kg} / \mathrm{m}^{3}$ is obtained to determine the mass, $m$ to be $1.145 \mathrm{~kg}$. The volume of the bird model is then determined as: 


$$
\begin{aligned}
& V=\frac{m}{\rho}=1.205 .10^{-3} \mathrm{~m}^{3} \\
& V=\frac{5 \pi D^{3}}{12} \rightarrow D=0.097 \mathrm{~m}
\end{aligned}
$$

Referring to Eq. (2), the volume is then used to calculate the diameter and length of the bird model as $0.097 \mathrm{~m}$ and $0.194 \mathrm{~m}$, respectively, as the length to radius ratio is equal to two.

Establishing the material of the bird would often depend on the internal organs of the bird, as would depend on different bird sizes or species. In numerical modelling, the bird's flesh, blood, and bones must be modelled as close to a real bird's innards as possible, where gelatin has been established as one of the materials used in simulating bird strikes. Real birds were launched from pressure nozzles to strike aircraft parts during early experimentations but this practice has since died down due to it being unsanitary as well as inhumane. Having to reuse or replace each bird during testing was not practical.

In Wilbeck's experiments, observations show that an important factor in bird strikes are the fact that birds can be considered as a fluid during high velocity impacts. Hence the use of SPH model would align with this factor as the splatter would spread the organs further. As such, Dar et al. [12] proposed the use of Elastic-Plastic-Hydrodynamic (EPH) material model to analyze the bird behavior through a polynomial equation of state. This is implemented through the LS-Dyna keyword manager in this paper.

The pressure-density relationship equation of state for the bird is expressed as an isotropic and non-viscous model, allowing the model to be used as a large strain during deformation and be defined with the yield stress and tangent modulus of the engine blade material. The pressure $\mathrm{P}$ is shown below:

$$
P=C_{0}+C_{1} \mu+C_{2} \mu^{2}+C_{3} \mu^{3}+\left(C_{4}+C_{5} \mu+C_{6} \mu^{2}\right) E
$$

The internal energy, E and the seven polynomial coefficients, $C_{i}$ are the basis of the polynomial equation of state and can be determined to model birds accurately. The relative density, $\mu$ is expressed as the ratio of the instantaneous density $\rho$ to initial density $\rho_{0}$ in Eq. (5):

$$
\mu=\left(\frac{\rho}{\rho_{0}}\right)-1
$$

As the bird is considered a fluid, Banerjee et al. states the coefficients $C_{4}, C_{5}, C_{6}$ are set to zero to match the behaviour of water. The equilibrium conditions would also mean that $C_{0}$ is set to zero. Therefore, the physical properties of the bird are presented below in Table 1.

Table 1: Bird physical properties [12]

\begin{tabular}{cccccc}
\hline $\begin{array}{c}\text { Density } \\
{\left[\mathbf{k g} / \mathbf{m}^{3}\right]}\end{array}$ & $\begin{array}{c}\text { Shear } \\
\text { Modulus } \\
{[\mathbf{G P a}]}\end{array}$ & $\begin{array}{c}\text { Yield Stress } \\
{[\mathbf{M P a}]}\end{array}$ & $\mathbf{C}_{\mathbf{1}}$ & $\mathbf{C}_{\mathbf{2}}$ & $\mathbf{C}_{\mathbf{3}}$ \\
\hline 950 & 2 & 0.02 & $2.1 \times 10^{9}$ & 6.2 & 10.1 \\
\hline
\end{tabular}

\section{POROUS ENGINE BLADE}

\subsection{Blade Material Model}

A Johnson-Cook material model is implemented in this paper as the material model of the engine blades. The damage assessed in this paper with a porous engine blade can be compared to the numerical computational bird strike by Shahimi et al. [8], it can be observed how a porous blade would compromise the structural integrity of the engine blade during 
bird strikes. High impact velocity would cause high elastic and inelastic strains, where there would be an impact load interaction between the bird and the engine blade. The JohnsonCook material is expressed with this high elastic and inelastic strain, thereby accurately simulating the bird strike computationally. The relation is expressed as follows:

$$
\sigma_{e q}=\left[A+B \varepsilon_{p}^{n}\right]\left[1+\operatorname{cln}\left(\dot{\varepsilon}^{*}\right)\right]\left[1-T^{* m}\right]
$$

The equivalent stress, $\sigma_{e q}$ is expressed as a function of plastic strain $\varepsilon$, strain rate $\dot{\varepsilon}$ and temperature, $T$. The function's constants are expressed in Table 2 by determining the constants of yield stress A, strain hardening parameter B, strain hardening exponent $\mathrm{n}$, strain rate sensitivity parameter $\mathrm{c}$, and temperature exponent $m$ for the material properties of aluminium. The material properties are implemented together with the equation of state as discussed previously in the bird model.

Table 2: Johnson-Cook failure model constants for aluminium [14]

\begin{tabular}{ccccccccc}
\hline $\begin{array}{c}\text { Yield } \\
\text { Stress } \\
{[\mathrm{MPa}]}\end{array}$ & $\begin{array}{c}\text { Strain } \\
\text { hardening } \\
\text { parameter } \\
{[\mathrm{MPa}]}\end{array}$ & $\begin{array}{c}\text { Strain } \\
\text { hardening } \\
\text { exponent }\end{array}$ & $\begin{array}{c}\text { Temperature } \\
\text { exponent }\end{array}$ & $\mathrm{D}_{1}$ & $\mathrm{D}_{2}$ & $\mathrm{D}_{3}$ & $\mathrm{D}_{4}$ & $\mathrm{D}_{5}$ \\
\hline 167 & $\mathbf{5 9 0}$ & $\mathbf{0 . 5 5 1}$ & $\mathbf{0 . 8 5 9}$ & $\mathbf{0 . 0 2 6 1}$ & $\mathbf{0 . 2 6 3}$ & $-\mathbf{- 0 . 3 4 9}$ & $\mathbf{0 . 2 4 7}$ & $\mathbf{1 6 . 8}$ \\
\hline
\end{tabular}

\subsection{Porous Blade Mesh and Assembly}

Porosity is defined as the ratio of void volume to the total volume or can also be the ratio of void area to the total area. The term porosity is defined as a section where there are tiny 'voids' that are littered on the surface area, that can be either regional or distributed. A regional porosity is more concentrated such as the leading edge of a wing airfoil section whereas distributed porosity would cover the whole cross-sectional area. As such, the relationship is defined as:

$$
\text { Porosity }(P)=\frac{\text { void volume }}{\text { total volume }}
$$

This porosity value can be increased depending on how many voids are covered throughout the whole cross-sectional area. The blade model is meshed as a hexahedron element to accurately observe the computational bird strike and is shown in Fig. 2(a). Figure 2(b) shows the area of $620209.73 \mathrm{~mm}^{2}$ with an arc length of $1099.71 \mathrm{~mm}$ at the leading edge where the porous holes are located along the arc. The porosity of the blade is featured as 5 $\mathrm{mm}$ diameter voids each spaced $5 \mathrm{~mm}$ apart. With around 103 holes distributed at the leading edge along the curvature, the porosity is determined with Eq. (7) to be $P=0.32 \%$ of the whole blade.

The blade assembly consists of 18 blades: equally spaced $20^{\circ}$ around the hub. Computationally, the bird interacts with the leading edge, slicing the bird slightly before striking the whole of its weight onto the blade leading edge that causes high deformation.

\section{COMPUTATIONAL RESULTS}

\subsection{Computational Simulation}

LS-Dyna prepost software was used to computationally mesh and simulate the bird strike impact onto a porous engine blade. The initial velocity of the bird is set to $\mathrm{v}=120$ $\mathrm{m} / \mathrm{s}$ from the basis of Wilbeck's experiment. The engine blades were set to $\omega=200 \mathrm{rad} / \mathrm{s}$ angular rotation to simulate a take-off and landing scenario set by Vingjevic et al. [9]. Much 
of the computational framework has been established through the keyword manager, where each of the bird model coefficients and blade material Johnson-Cook failure constants were implemented. The numerical framework established by Vingjevic et al. [9] provided much of the initial bird velocity, initial rotation of the engine blades and the implementation of a damage model.

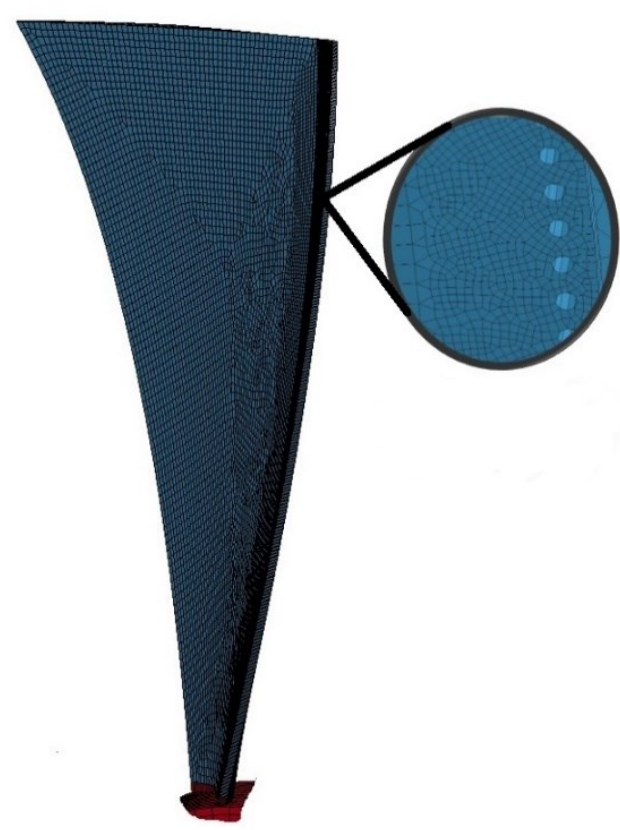

(a)

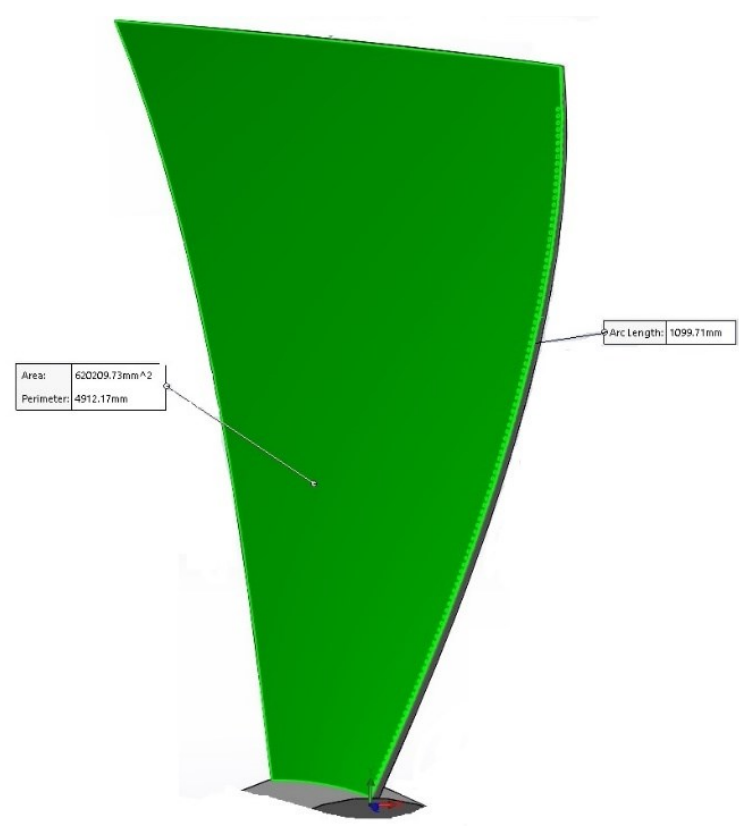

(b)

Fig. 2: (a) Blade mesh assembly, (b) Blade geometry.

This paper studies closely the methodology and numerical framework established by Vingjevic. Vinjevic's failure model was analyzed as a Grüneisen parameter, this paper utilizes the keyword manager of LS-Dyna in conjunction with the numerical methods done by Vingjevic et al. [9]. It is shown that initial stresses appear at the blade's root due to the engine's rotation creating centrifugal forces. The stresses caused by these centrifugal forces can contribute to the load deformation once impact occurs. The termination time was set to $10 \mathrm{~ms}$ to allow observation of the bird impact into the subsequent blade after the initial impact. The simulation results are presented in Fig. 5 (a), (b), (c), (d), (e), and (f) where the impact loads are shown at $2 \mathrm{~ms}, 3 \mathrm{~ms}, 4 \mathrm{~ms}, 5 \mathrm{~ms}, 6 \mathrm{~ms}$, and $7 \mathrm{~ms}$ respectively. The numerical analysis is presented as impact loads of Von-Mises effective stress. It is observed in Fig. 5 that as the bird impacts the blade, high stress occurs and bends the leading edge of the engine blade, thus causing deformation.

\subsection{Computational Approach Validation}

The computational method presented for this work is validated through a parametric study of bird strikes on engine blades done by Vingjevic et al. [9]. The research performed by Vingjevic et al. [9] utilised a Grüneisen parameter done through LS-Dyna Keyword manager and the polynomial equations of state of the bird model. The studies show that there are fringe levels and initial stresses (v-M) due to centrifugal forces. Figure 4 shows the resultant displacement $(\mathrm{mm})$ or deformations caused by the bird strike impact along the leading edge and located at the porous regions. The trend here indicates that the bending forces and centrifugal force are consistent at the leading edge despite different modelling 
parameters. The displacement shown at the leading edge has proven that the method used here can be utilized to the same effect.

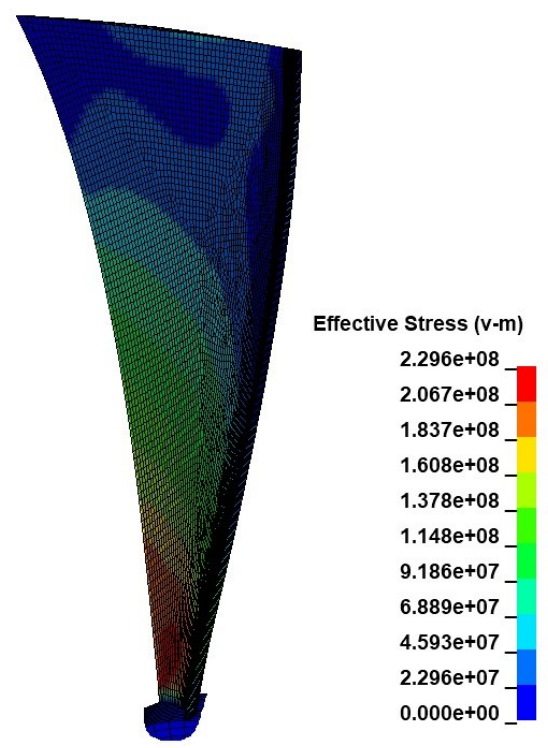

Fig. 3: Initial stresses occur at the root due to centrifugal forces.

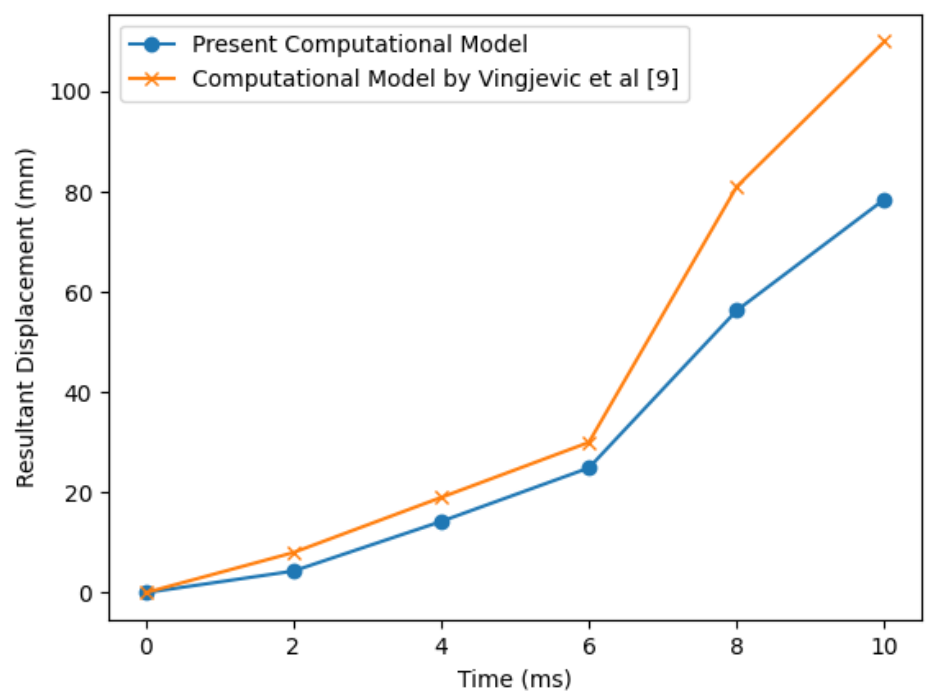

Fig. 4: Numerical validation through resultant displacement of present work with the computational result by Vingjenic et al. [9] based at the leading-edge.

\subsection{Computational Results}

The blade mesh geometry does flow well with the impact of the bird during computation. Despite the porous regions being more exposed to heavy impact, this allows the structure to be more visualized in many other aspects of the study. Effective stress here would be consistent with the validated procedures and show the behavior of the fluid flow structure interaction between the bird and the blade. The effective mean stress thus relates to the equivalent stress from the Johnson-Cook relationship that was defined. It is now 
observed that a bird strike event can be computationally composed through the implemented method.

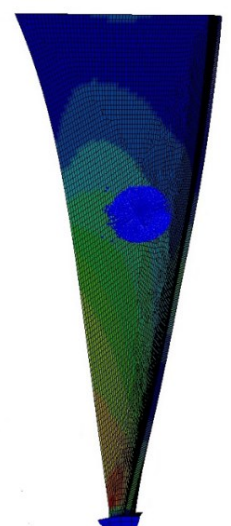

Effective Stress (v-m)

$2.840 \mathrm{e}+08$

$2.556 \mathrm{e}+08$

$2.272 e+08$

$1.988 \mathrm{e}+08$

$1.704 \mathrm{e}+08$

$1.420 \mathrm{e}+08$

$1.136 \mathrm{e}+08$

$8.519 \mathrm{e}+07$

$5.679 e+07$

$2.840 e+07$

$0.000 \mathrm{e}+00$

(a)

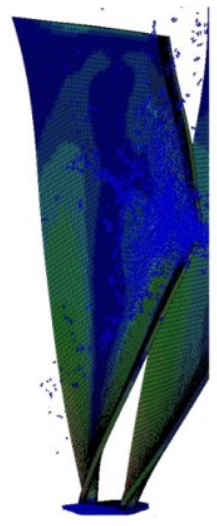

Effective Stress (v-m)

$3.689 \mathrm{e}+08$

$3.320 \mathrm{e}+08$

$2.952 e+08$

$2.583 e+08$

$2.214 \mathrm{e}+08$

$1.845 \mathrm{e}+08$

$1.476 \mathrm{e}+08$

$1.107 \mathrm{e}+08$

$7.379 \mathrm{e}+07$

$3.689 \mathrm{e}+07$

$0.000 \mathrm{e}+00$

(c)

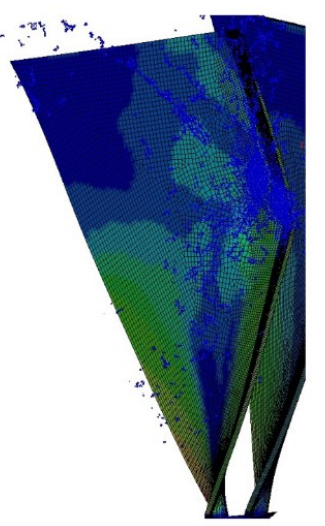

(e)

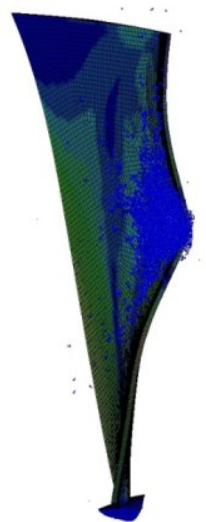

Effective Stress (v-m)

$3.339 \mathrm{e}+08$

$3.005 e+08$

$2.671 \mathrm{e}+08$

$2.337 e+08$

$2.003 e+08$

$1.669 \mathrm{e}+08$

$1.335 \mathrm{e}+08$

$1.002 \mathrm{e}+08$

$6.677 \mathrm{e}+07$

$3.339 \mathrm{e}+07$

$0.000 \mathrm{e}+00$

(b)

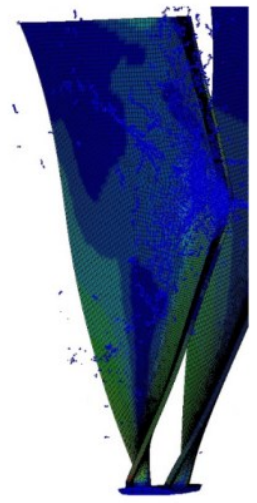

Effective Stress (v-m)

$4.703 e+08$

$4.233 e+08$

$3.762 \mathrm{e}+08$

$3.292 \mathrm{e}+08$

$2.822 \mathrm{e}+08$

$2.352 e+08$

$1.881 \mathrm{e}+08$

$1.411 \mathrm{e}+08$

$9.406 \mathrm{e}+07$

$4.703 e+07$

$0.000 \mathrm{e}+00_{-}$

(d)

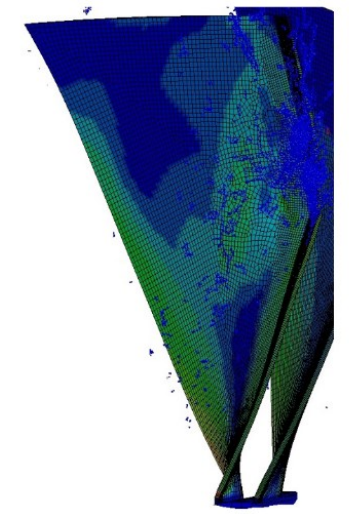

Effective Stress (v-m)

$4.245 \mathrm{e}+08$

$3.821 \mathrm{e}+08$

$3.396 \mathrm{e}+08$

$2.972 \mathrm{e}+08$

$2.547 \mathrm{e}+08$

$2.123 e+08$

$1.698 \mathrm{e}+08$

$1.274 \mathrm{e}+08$

$8.491 \mathrm{e}+07$

$4.245 \mathrm{e}+07$

$0.000 \mathrm{e}+00$

(f)

Fig. 5: V-M stresses (kPa) at time intervals (a) $2 \mathrm{~ms}$, (b) $3 \mathrm{~ms}$, (c) $4 \mathrm{~ms}$, (d) $5 \mathrm{~ms}$, (e) $6 \mathrm{~ms}$, and (f) 7 $\mathrm{ms}$.

When the bird interacts with the blade structure, the bird behaves as a fluid body, the SPH particles move individually, impacting and spreading the splatter throughout the whole surface of the blade. It is observed here that the impact point at the leading edge shows significant damage at the root and the leading edge where the voids are located. The impact at $2 \mathrm{~ms}$ in Fig. 5(a) is the initial condition just before impact where the bird travels at 120 $\mathrm{m} / \mathrm{s}$ at the blade rotating at $200 \mathrm{rad} / \mathrm{s}$. At $3 \mathrm{~ms}$ in Fig. 5(b), the bird smashes into the leading 
edge, causing high deformation, and damaging the blade completely, bending the root at $339 \mathrm{MPa}$. Part of the bird splatter then moves on to the subsequent blade and also damages part of that blade with the stresses increasing for each subsequent time frame as shown in Fig. 5 (c), (d), (e), and (f).

\subsection{Effect of Porosity}

This paper investigates the effect of porosity implemented on the leading edge of a rotating engine blade. The effect of porosity compromises the structural integrity of the engine blade, causing higher deformation. Referring to Fig. 6(a) shows the porous blade while Fig. 6(b) shows a normal engine blade. The deformation of both the engine blades are slight while focusing on the blue region where the deformation of the model with small holes has slightly more deflection in $\mathrm{z}$ direction ( 0.1349 meters) while the model with no hole's deflection is only 0.1127 meters. Due to the holes disturbing the flow of the bird particles, the SPH particles become lodged into porous regions, interrupting the flow of impact as compared to the normal engine blade as shown in Fig. 5 (c), (d), (e), and (f).

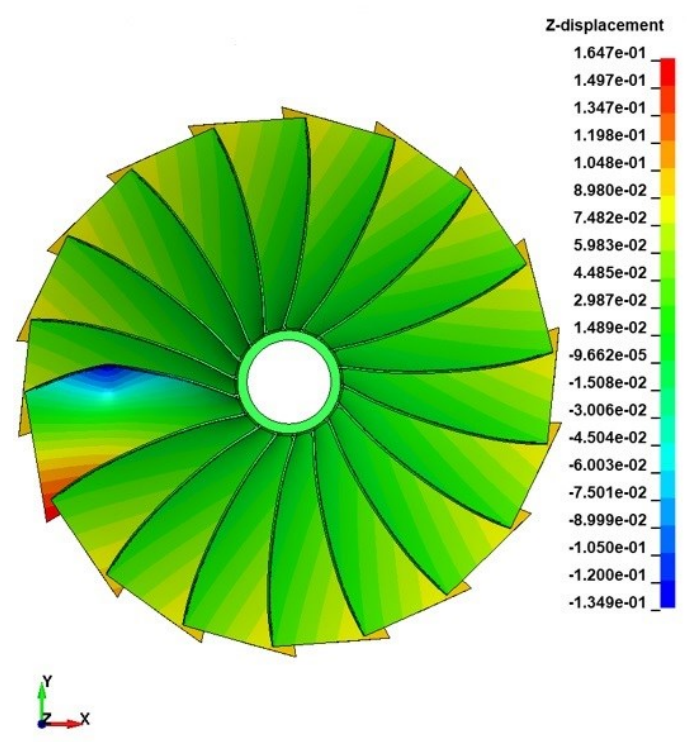

(a)

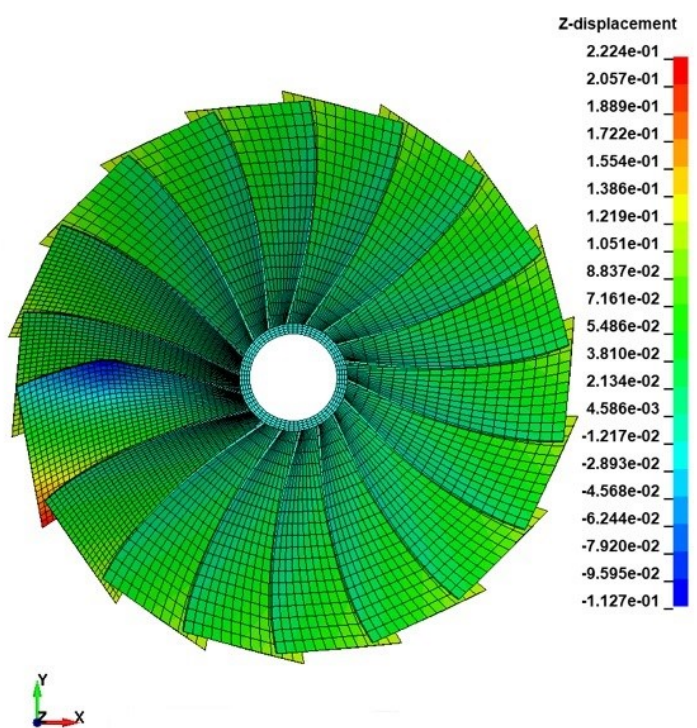

(b)

Fig. 6: z-displacement of jet engine blade after bird strike.

This comparison can be further analyzed by the energy absorbed by the jet engine blades. Referring to Fig. 7, the energy absorbed by both blade types see a slight drop after the initial impact as all the weight of the bird is concentrated at a that one point of impact. At $2 \mathrm{~ms}$, when the bird has impacted the blade, the energy absorbed by both blades; porous and non-porous appear to be similar, since the bird has only impacted the smooth part of both blades, however, as soon as the SPH particles spread, it is more prevalent on the porous blade, the particles are lodged in the porous region and the voids absorb the energy of the impact, thus creating a higher change in absorbed energy for the porous blade at $4 \mathrm{~ms}$. At 6 $\mathrm{ms}$, the SPH particles have mainly swept off for the non-porous blade, as the flow of particles are much smoother, but for the porous blade, the jump in energy shows that the lodged particles observe a high increase in energy. After, $8 \mathrm{~ms}$, most of the particles have spread around each blade, stabilizing the energy absorbed for the non-porous but increasing much more for the porous region. 


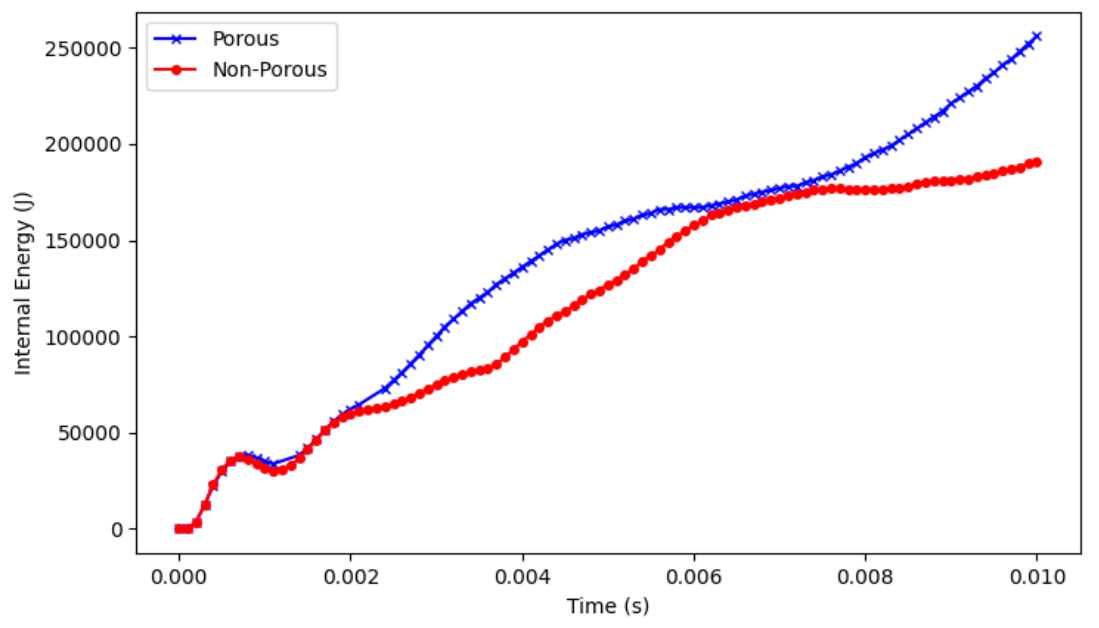

Fig. 7: Internal energy (J) vs Time (s) for porous and non-porous blade.

\section{CONCLUSION}

This paper analyses the damage of a numerically modelled porous engine blade subjected to bird strike. The bird is modelled as a hemispherical SPH particle model to accurately splatter the rotating engine blades at $120 \mathrm{~m} / \mathrm{s}$. The computational result for the porous blade observes a high impact damage at the porous region where the SPH particles spread and lodge within the voids of the porous, creating a high energy absorption compared to a non-porous engine blade for as much as $38.6 \mathrm{~kJ}$ or $39.63 \%$ increase at $4 \mathrm{~ms}$. Even the non-porous blade has stabilized by the end of $10 \mathrm{~ms}$, whereby the porous blade sees an increase in the energy absorbed, damage is prevalent enough for as much as $65 \mathrm{~kJ}$ or $34.03 \%$. Bird strikes are indeed shown to be dangerous even for a normal engine blade used today. The compromise to the structural integrity of the engine blade is significant if a porous engine blade were to be implemented. As the energy absorbed is higher, the impact reaction toward the engine turbine can cause a very dangerous scenario in the event of a bird strike accident.

In terms of energy absorbed, since even though the voids contain no mass, the SPH particles are still lodged within the voids by the impact energy transferred by the bird momentum from the initial velocity onto the engine blades. The entire strength of the structure however has been reduced, the porosity on the leading edge is minuscule in that it would not really reduce the strength of the structure but since the bird struck directly at that area, the damage is still significant and the energy absorbed is still increased. Where there are voids located in the structure, the vibrational energy is still considered even though there is no mass to absorb the energy [11].

\section{ACKNOWLEDGEMENT}

The authors would like to express their gratitude and thanks to the Ministry of Higher Education Malaysia and the International Islamic University Malaysia for funding this research under the Fundamental Research Grant Scheme for Research Acculturation of Early Careers (RACER/1/2019/TK09/UIAM//1).

\section{REFERENCES}

[1] Thorpe J. (2012) 100 years of fatalities and destroyed civil aircraft due to bird strikes. 30th Meeting of the International Bird Strike Committee, 1-36. 
[2] Wilbeck JS, Rand JL. (1981) The development of a substitute bird model. J. Engineering for Gas Turbines and Power, 103(4):725-730.

[3] Liu J, Li Y, Gao X. (2014) Bird strike on a flat plate: Experiments and numerical simulations. Int. J. Impact Engineering, 70:21-37.

[4] Guan Y, Zhao Z, Chen W, Gao D. (2008) Foreign objecct damage to fan rotor blades of aeroengine part II: Numerical simulation of bird impact. Chinese J. Aeronautics, 21(4):328334.

[5] Abdullah NA, Akbar M, Wirawan N, Curiel-Sosa JL. (2019) Structural integrity assessment on cracked composites interaction with aeroelastic constraint by means of XFEM. Composite Structures, 229.

[6] Wirawan N, Abdullah NA, Akbar, Curiel-Sosa JL. (2018) Analysis on cracked commuter aircraft wing under dynamic cruise load by means of XFEM. J. Physics: Conference Series, 1106(1).

[7] Ahmad MIM, Curiel-Sosa JL, Akbar M, Abdullah NA. (2018) Numerical inspection based on quasi-static analysis using Rousselier damage model for aluminium wingbox aircraft structure. J. Physics: Conference Series, 1106(1).

[8] Shahimi SS, Abdullah NA, Hrairi M, Ahmad MIM. (2021) Numerical investigation on the damage of whirling engine blades subjected to bird strike impact. J Aeronautics, Astronautics and Aviation, 53(2):193-200.

[9] Vignjevic R, Orlowski M, De Vuyst T, Campbell JC. (2013) A parametric study of bird strike on engine blades. Int. J. Impact Engineering, 60:44-57.

[10] Aldheeb M, Asrar W, Sulaeman E, Omar AA. (2018) Aerodynamics of porous airfoils and wings. Acta Mechanica, 229(9):3915-3933.

[11] Kovalev IS. (2019) Buttefly acoustical skin - new method of reducing aero acoustical noise for a quiet propeller. J. Engineering Mechanics and Machinery, 4(1):1-28.

[12] Dar UA, Awais M, Mian HH, Sheikh MZ. (2019) The effect of representative bird model and its impact direction on crashworthiness of aircraft windshield and canopy structure. Proceedings of the Institution of Mechanical Engineers, Part G: J. Aerospace Engineering, 233(14):5150-5163.

[13] Riccio A, Cristiano R, Saputo S. (2016) A brief introduction to the bird strike numerical simulation. American J. Engineering and Applied Sciences, 9(4):946-950.

[14] Banerjee A, Dhar S, Acharyya S, Datta D, Nayak N. (2015) Determination of Johnson Cook material and failure model constants and numerical modelling of Charpy impact test of armour steel. Materials Science and Engineering, 640:200-209. 